\title{
PERSPECTIVE
}

\section{Conscientious Objections during COVID-19 Pandemic}

\section{Deepak Gupta}

Clinical Assistant Professor, Anesthesiology, Wayne State University, Detroit, Michigan United States

Abstract Introduction Methodology Results Conclusion References Citation Tables/ Figures

\section{Corresponding Author}

Dr Deepak Gupta, Clinical Assistant Professor, Anesthesiology, Detroit Medical Center/Wayne

State University, Box No 162, 3990 John R, Detroit, Ml 48201, United States

E Mail ID: dgupta@med.wayne.edu

\section{Citation}

Gupta D. Conscientious Objections during COVID-19 Pandemic. Indian J Comm Health. 2020;32(2-Special Issue):231-235.

Source of Funding: Nil Conflict of Interest: None declared

\section{Article Cycle}

Received: 04/04/2020; Revision: 13/04/2020; Accepted: 15/04/2020; Published: 20/04/2020

This work is licensed under a Creative Commons Attribution 4.0 International License.

\section{Abstract}

Globally evolving COVID-19 pandemic has raised major questions which may have catastrophic implications like absence of universal facemask use, misunderstanding implications of SARS-CoV-2 test results, ventilator related mortality, cytokine reduction technology and anti-viral treatments being in their infancy still, failure to update advanced healthcare directives during pandemic, and overlooked home hospice options for COVID-19 patients when terminally ill. Moreover, there are inquisitive and interesting avenues worth exploring and innovating during COVID19 pandemic like "cold" viruses such as SARS-CoV-2 uniquely choosing airways which normally and naturally have temperatures much lower than core body temperatures, potential therapeutic role (if any) of facemask usage, potential role of natural disinfection by sunlight and its component ultraviolet- $C$ which is used for artificial cleansing, potential bimodal immune response against SARS-CoV-2, and exploration into BCG vaccination based non-specific protection against intracellular pathogens with SARS-CoV-2 itself being an intracellular pathogen. Summarily, I am praying that the natural delays in establishing reproducible evidence during COVID-19 pandemic should not turn the humanity as we know today into a historical evidence.

\section{Keywords}

Conscientious Objections; COVID-19; Pandemic

Globally evolving COVID-19 pandemic has raised major questions which may have catastrophic implications:

1. Besides handwashing and social distancing, how did South Korea and Japan (1-3) preemptively advocate facemasks to perform better against COVID-19 while facemask-specific recommendations of World Health Organization (WHO) and Centers for Disease Control and Prevention $(C D C)$ have taken longer time to evolve (4-7)?

2. Why are populations, providers and politicians feeling falsely reassured when testing negative for SARS-CoV-2 despite knowing that after testing negative on a given day, they can always test positive for SARS-CoV-2 later on if they are not completely isolating themselves immediately after testing negative for SARSCoV-2? Won't the quarantining of non-COVID-19 patients during the accelerated COVID-19 pandemic be specially applicable for untested pregnant patients who may or may not be vertically transmitting (8-9) "cold" viruses like SARS-CoV-2 through their "warm" blood and thus after delivering their non-COVID-19 newborns have to isolate their non-COVID-19 newborns from themselves until they themselves test negative as non-COVID-19 mothers where after they can room-in while 
nursing their non-COVID-19 newborns and being quarantined together?

3. How important is the shortage of ventilators if invasive mechanical ventilation may be proving futile for higher percentage of COVID-19 patients (10-11) secondary to ongoing anti-viral therapy trials not yet containing catastrophic immune responses induced by SARS-CoV-2 against human cardiopulmonary systems? Shouldn't the non-invasive ways of delivering positive end expiratory pressures (12-13) be explored to delay invasive mechanical ventilation use?

4. Isn't the shortage of awake spontaneously breathing extracorporeal membrane oxygenation (ECMO) with hemo-adsorption based cytokine reduction important too along with corresponding shortage of personnel and facilities to manage COVID-19 patients on awake ECMO (14) while awaiting anti-viral therapies to be successful against SARS-CoV-2? Will recently approved apheresis system (15) to clear cytokines be a "game-changer"?

5. How can advance healthcare directives (16) be informatively updated by awake, alert and oriented (to person, place, time and situation) COVID-19 patients and their families unless countries globally regularly update their intubated and mechanically ventilated COVID-19 patients' mortality (or survival) data (11)?

6. When will the role of home hospice (17) isolation chambers/tents for COVID-19 patients with provisions for oxygen supplementation and pain-symptom management at such home hospice isolated environments be explored for terminally ill COVID-19 patients who are choosing to stay isolated and yet nearer to their families and friends during their end-of-life periods?

Moreover, there are inquisitive and interesting avenues worth exploring and innovating during COVID-19 pandemic:

1. Why do "cold" viruses like SARS-CoV-2 primarily choose inhalational route rather than orogastrointestinal or blood transmission unless central as well as peripheral airway temperatures being colder (18-21) than core body temperatures is essential for these "cold" viruses like SARS-CoV-2 to reach the depths of human lungs which they intend to destruct?

2. Even though the actual rate of viral shedding may remain same in the oral cavity, do warm mist (22-25), fluids and foods decrease body's total viral load available for shedding (and thus for inhaling) by deactivating "cold" viruses like SARS-CoV-2 on contact before getting them ingested orally and excreted in feces as "deactivated" viral fragments unless warm mist, fluids and foods are just transiently containing local viral activity inside the oral and oropharyngeal cavity which may often be misinterpreted as non-specific symptom relief during the season of active and hyperactive "cold" viruses like SARS-CoV-2?

3. Does the binding of "cold" viruses like SARS-CoV2 to the pulmonary receptors (26-27) decrease with elevation of airways' temperatures around those pulmonary receptors?

4. Is there a therapeutic role for facemasks considering that while wearing appropriately fitting facemasks, people may be constantly inhaling their own warm mist laden exhalations leading to overall elevation of their airways' temperatures in contrast to their airways' temperatures being constantly exposed to colder dryer ambient atmosphere inhalations during their non-masked living in enclosed and controlled indoor environments?

5. Is there a role for sunlight based "disinfection" (28) by having clear top make-shift tents and clear roofed intensive care units utilizing the balance between protective and destructive effects of ultraviolet rays in the natural sunlight after comprehensively addressing patients' privacy concerns when cared inside clear top tents and clear roofed units?

6. Is there a bimodal pattern (29-31) of overall immune response to COVID-19 wherein (a) an appropriate combination of innate and acquired immune responses (primary, secondary, tertiary and quaternary) keeps COVID-19 patients safely 
manageable at home while (b) the catastrophic combination of innate and acquired immune systems erratically storms the body with innate and acquired immune responses (primary, secondary, tertiary and quaternary) leading to COVID-19 patients' deaths despite intensive care management, but then again (c) the unique combination of innate and acquired immune systems surrender to SARS-CoV-2 whereby they fail to mount any innate or acquired immune responses (primary, secondary, tertiary and quaternary) and thus save COVID-19 patients due to absence of all immunomodulation?

7. What can be preventing the exploration of universal BCG vaccination (32) among the countries which have not usually performed it due to low incidence and prevalence of tuberculosis within their borders? Won't they have to consider sooner than later to potentially explore benefits of universal BCG vaccination in non-specifically protecting against severity of COVID-19 while the world is awaiting laboratory development, clinical investigation, mass production and mass vaccination with SARSCoV-2 specific vaccine that may take more than one year? Can only BCG vaccine provide protection or does history of treated and resolved latent tuberculosis infection or active tuberculosis (33-34) too provide the same protection as BCG vaccine by inducing similar acquired immune responses (primary, secondary, tertiary and quaternary) which may be keeping COVID-19 patients safely manageable at home?

In a nutshell, even though almost all of the abovementioned listed ideologies may have already been shared online in some form, I am sharing the abovementioned non-comprehensive list of thoughts and ideas for the sake of robotic analysts (35-37) which may seem to prefer reputed outlets while mining data for analysis and recommendations. I hope that robotic data miners can capture the issues raised herein and present to leading human researchers globally who can consider exploring them during their pursuits to overcome COVID-19 pandemic because the natural and beyond-human-control delays in establishing reproducible evidence during COVID-19 pandemic should not turn the humanity as we know today into a historical evidence for our future generations, who will review, analyze and introspect humanity as we now today becoming a historical case study for them.

Disclaimer

I may neither take credit for myself nor give credit to anyone else because I may be just acting as one miniscule output signal from the globalized virtual unity during the rapidly evolving COVID-19 pandemic globally.

\section{Acknowledgement}

I dedicate this written piece to my inspiring and inspirational peers, Dr. Shushovan Chakrabortty, Dr. Sarwan Kumar and Dr. Arvind Srirajakalidindi

References

1. Snyder SA. Unmasking Differing U.S. and South Korean Approaches to COVID-19. Available at https://www.cfr.org/blog/unmasking-differing-us-andsouth-korean-approaches-covid-19

2. Fritz M. Coronavirus: How Japan keeps COVID-19 under control. Available

at https://www.dw.com/en/coronavirus-how-japan-keepscovid-19-under-control/a-52907069

3. Smith C. Coronavirus transmission video shows why we should all be wearing masks. Available at https://bgr.com/2020/03/30/coronavirus-update-newresearch-suggests-we-should-be-wearing-masks/

4. Centers for Disease Control and Prevention. Recommendation regarding the use of cloth face coverings, especially in areas of significant communitybased transmission. Available at https://www.cdc.gov/coronavirus/2019-ncov/preventgetting-sick/cloth-face-cover.html

5. Aiello AE, Perez V, Coulborn RM, Davis BM, Uddin M, Monto AS. Facemasks, hand hygiene, and influenza among young adults: a randomized intervention trial. PLoS One. 2012;7(1):e29744. doi:10.1371/journal.pone.0029744. Available at https://www.ncbi.nlm.nih.gov/pmc/articles/PMC326625 7/

6. Cowling BJ, Zhou Y, Ip DK, Leung GM, Aiello AE. Face masks to prevent transmission of influenza virus: a systematic review. Epidemiol Infect. 2010 Apr;138(4):44956. doi:10.1017/S0950268809991658. Available at https://www.cambridge.org/core/journals/epidemiology -and-infection/article/face-masks-to-preventtransmission-of-influenza-virus-a-systematicreview/64D368496EBDEOAFCC6639CCC9D8BC05

7. Aiello AE, Murray GF, Perez V, Coulborn RM, Davis BM, Uddin M, Shay DK, Waterman SH, Monto AS. Mask use, hand hygiene, and seasonal influenza-like illness among young adults: a randomized intervention trial. J Infect Dis. 2010 Feb 15;201(4):491-8. doi:10.1086/650396. Available 
at

https://academic.oup.com/jid/article/201/4/491/861190

8. Dong L, Tian J, He S, Zhu C, Wang J, Liu C, Yang J. Possible Vertical Transmission of SARS-CoV-2 From an Infected Mother to Her Newborn. JAMA. 2020 Mar 26. doi:10.1001/jama.2020.4621. Available at https://jamanetwork.com/journals/jama/fullarticle/2763 853

9. Chen H, Guo J, Wang C, Luo F, Yu X, Zhang W, Li J, Zhao D, Xu D, Gong $Q$, Liao J, Yang H, Hou W, Zhang Y. Clinical characteristics and intrauterine vertical transmission potential of COVID-19 infection in nine pregnant women: a retrospective review of medical records. Lancet. 2020 Mar 7;395(10226):809-815. doi:10.1016/S01406736(20)30360-3. Available at https://www.thelancet.com/journals/lancet/article/PIISO 140-6736(20)30360-3/fulltext

10. Weiss $\mathrm{P}$, Murdoch DR. Clinical course and mortality risk of severe COVID-19. Lancet. 2020 Mar 28;395(10229):1014-1015. doi:10.1016/S01406736(20)30633-4. Available at https://www.thelancet.com/journals/lancet/article/PIISO 140-6736(20)30633-4/fulltext

11. Intensive Care National Audit \& Research Center. ICNARC report on COVID-19 in critical care: 10 April 2020. Available at https://www.icnarc.org/DataServices/Attachments/Dow nload/c31dd38d-d77b-ea11-9124-00505601089b

$12 . \quad H e l m e t-b a s e d$ ventilation is a solution for COVID19 treatment. Available at https://www.helmetbasedventilation.com/

13. e Vet B. 3D-printed non-invasive PEEP masks aim to alleviate ventilator shortage. Available at https://www.materialise.com/en/blog/3d-printed-peepmask-alleviate-ventilator-shortage

14. Ding L, He H. Awake Extracorporeal Membrane Oxygenation for Acute Respiratory Distress Syndrome, Details to Be Defined: Who, When, and How? Crit Care Med. 2019 Dec;47(12):e1038. doi:10.1097/CCM.0000000000003961. Available at https://journals.Iww.com/ccmjournal/Citation/2019/120 00/Awake Extracorporeal Membrane Oxygenation for. 47.aspx

15. U.S. Food \& Drug Administration. Coronavirus (COVID-19) Update: FDA authorizes blood purification device to treat COVID-19. Available at https://www.fda.gov/news-events/pressannouncements/coronavirus-covid-19-update-fdaauthorizes-blood-purification-device-treat-covid-19

16. Irving S. Coronavirus Preparation: Now is the Time to Make a Living Will \& Medical Power of Attorney. Available at https://www.nolo.com/legalencyclopedia/coronavirus-preparation-now-is-the-timeto-make-a-living-will.html

17. Centers for Medicare \& Medicaid Services. Hospice: CMS flexibilities to fight COVID-19. Available at
(Conscientious Objections) | Gupta D et al https://www.cms.gov/files/document/covidhospices.pdf

18. McFadden ER Jr, Pichurko BM, Bowman HF, Ingenito $\mathrm{E}$, Burns S, Dowling N, Solway J. Thermal mapping of the airways in humans. J Appl Physiol. 1985 Feb;58(2):564-70. Available at https://journals.physiology.org/doi/abs/10.1152/jappl.1 985.58.2.564

19. McFadden ER Jr, Denison DM, Waller JF, Assoufi B, Peacock A, Sopwith T. Direct recordings of the temperatures in the tracheobronchial tree in normal man. J Clin Invest. 1982 Mar;69(3):700-5. Available at https://www.ncbi.nlm.nih.gov/pmc/articles/PMC371028 L

20. ngenito EP, Solway J, McFadden ER Jr, Pichurko B, Bowman HF, Michaels D, Drazen JM. Indirect assessment of mucosal surface temperatures in the airways: theory and tests. J Appl Physiol (1985). 1987 Nov;63(5):2075-83. Available at https://journals.physiology.org/doi/abs/10.1152/jappl.1 987.63.5.2075

21. McFadden ER Jr, Pichurko BM. Intraairway thermal profiles during exercise and hyperventilation in normal man. J Clin Invest. 1985 Sep;76(3):1007-10. Available

at https://www.ncbi.nlm.nih.gov/pmc/articles/PMC423970 L

22. Singh $M$, Singh $M$, Jaiswal N, Chauhan A. Heated, humidified air for the common cold. Cochrane Database Syst Rev. $2017 \quad$ Aug 29;8:CD001728. doi:10.1002/14651858.CD001728.pub6. Available at https://www.ncbi.nlm.nih.gov/pmc/articles/PMC648363 2/

23. Wolkoff P. Indoor air humidity, air quality, and health - An overview. Int J Hyg Environ Health. 2018 Apr;221(3):376-390. doi:10.1016/j.ijheh.2018.01.015. Available at https://www.sciencedirect.com/science/article/pii/S143 8463917306946

24. Hathaway B. Hopes of pandemic respite this spring may depend upon what happens indoors. Available at https://news.yale.edu/2020/03/30/hopes-pandemicrespite-spring-may-depend-upon-what-happens-indoors

25. Moriyama M, Hugentobler WJ, Iwasaki A. Seasonality of Respiratory Viral Infections. Annu Rev Virol. 2020 Mar 20. doi:10.1146/annurev-virology-012420022445. Available at https://www.annualreviews.org/doi/abs/10.1146/annur ev-virology-012420-022445

26. Hamming I, Timens W, Bulthuis ML, Lely AT, Navis $G$, van Goor $H$. Tissue distribution of ACE2 protein, the functional receptor for SARS coronavirus. A first step in understanding SARS pathogenesis. J Pathol. 2004 Jun;203(2):631-7. Available at https://onlinelibrary.wiley.com/doi/full/10.1002/path.15 $\underline{70}$ 
27. Hoffmann $M$, Kleine-Weber $H$, Schroeder $S$, Krüger N, Herrler T, Erichsen S, Schiergens TS, Herrler $G$, Wu NH, Nitsche A, Müller MA, Drosten C, Pöhlmann S. SARS-CoV-2 Cell Entry Depends on ACE2 and TMPRSS2 and Is Blocked by a Clinically Proven Protease Inhibitor. Cell. 2020 Mar 4. pii: S0092-8674(20)30229-4. doi:10.1016/j.cell.2020.02.052. Available at https://www.cell.com/cell/fulltext/S00928674(20)30229-4

28. O’Neil K. Grandma Was Right: Sunshine Helps Kill Germs Indoors. Available at https://www.npr.org/sections/healthshots/2018/10/18/658335490/grandma-was-rightsunshine-helps-kill-germs-indoors

29. Raoult D, Zumla A, Locatelli F, Ippolito G, Kroemer G. Coronavirus infections: Epidemiological, clinical and immunological features and hypotheses. Cell Stress. 2020 Mar 2. doi:10.15698/cst2020.04.216. Available https://www.ncbi.nlm.nih.gov/pmc/articles/PMC706401 8/

30. D'Antiga L. Coronaviruses and immunosuppressed patients. The facts during the third epidemic. Liver Transpl. 2020 Mar 20. doi: 10.1002/lt.25756. Available at https://aasldpubs.onlinelibrary.wiley.com/doi/10.1002/lt .25756

31. Ye G, Pan Z, Pan Y, Deng Q, Chen L, Li J, Li Y, Wang $X$. Clinical characteristics of severe acute respiratory syndrome coronavirus 2 reactivation. J Infect. 2020 Mar $20 . \quad$ pii: S0163-4453(20)30114-6. doi:10.1016/j.jinf.2020.03.001. Available at https://www.ncbi.nlm.nih.gov/pmc/articles/PMC710256 0/
32.

(Conscientious Objections) | Gupta D et al
Fasciglione, Violeta Roumenova, Yan Li, Gonzalo H Otazu. Correlation between universal BCG vaccination policy and reduced morbidity and mortality for COVID-19: an epidemiological study. medRxiv 2020.03.24.20042937. doi:10.1101/2020.03.24.20042937. Available at https://www.medrxiv.org/content/10.1101/2020.03.24. 20042937v1

33. Ehlers S. Immunity to tuberculosis: a delicate balance between protection and pathology. FEMS Immunol Med Microbiol. 1999 Feb;23(2):149-58. Available https://academic.oup.com/femspd/article/23/2/149/514 $\underline{150}$

34. Liu Y, Bi L, Chen Y, Wang Y, Fleming J, Yu Y, Gu Y, Liu C, Fan L, Wang $X$, Cheng $M$. Active or latent tuberculosis increases susceptibility to COVID-19 and disease severity. medRxiv 2020.03.10.20033795. doi:10.1101/2020.03.10.20033795. Available at https://www.medrxiv.org/content/10.1101/2020.03.10. 20033795v1

35. Wood C. Robot analysts are better than humans at picking stocks, a new study found. Available at https://www.businessinsider.com/robot-analysts-betterthan-humans-at-picking-good-investments-study-2020-2

36. Coleman B, Merkley KJ, Pacelli J. Man versus Machine: A Comparison of Robo-Analyst and Traditional Research Analyst Investment Recommendations. SSRN. 2020 February 20. Available at https://ssrn.com/abstract=3514879

37. Data Robot. Healthcare. Available at https://www.datarobot.com/solutions/healthcare/ 